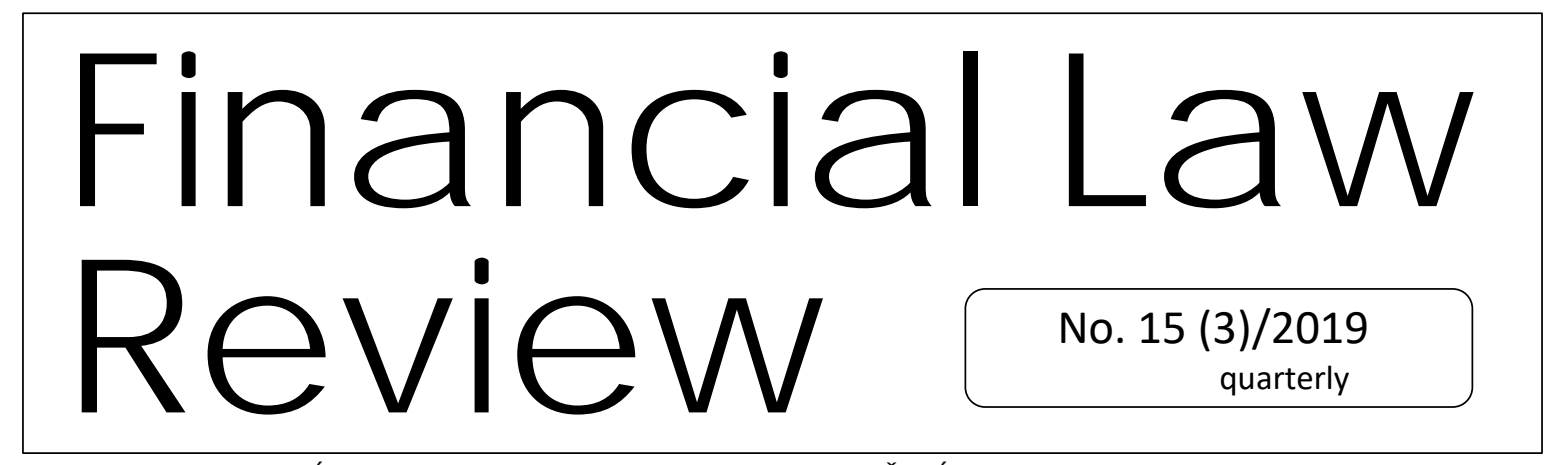

UNIVERSITY OF GDAŃSK • MASARYK UNIVERSITY • PAVEL JOZEF ŠAFÁRIK UNIVERSITY • UNIVERSITY OF VORONEZH http://www.ejoumals.eu/FLR

\title{
THE USE OF INFORMATION TECHNOLOGIES TO INVOLVE CITIZENS IN THE BUDGET PROCESS AT THE MUNICIPAL LEVEL: EXPERIENCE OF RUSSIA AND FOREIGN COUNTRIES SVETLANAMIRONOV A*
}

\begin{abstract}
The development of information technologies, including in the financial sphere, allows to increase the number of citizens involved in the budget process, thereby helps to increase control over the targeted expenditure of funds, the quality of budget decisions and budget execution, increases the responsibility of local authorities. The article shows how the use of information technologies, including Internet resources, as well as the latest digital technologies, such as blockchain, help to involve citizens in the budget process. Attention is drawn to the need for financial support for the use of information technology, both through budget funds and through the attraction of grants. The author uses scientific methods of analysis, synthesis, and comparison.
\end{abstract}

\footnotetext{
${ }^{*}$ Candidate of juridical sciences, Associate Professor, Department of entrepreneurial and financial and tax law, Volgograd Institute of Management - branch of the RANEPA, Gagarina street, 8, Volgograd, 400131, Russia. Specialist in the field of financial law, research interests - financial and legal status of municipalities. Author of more than 130 publications, including monographs, textbooks. Member of the Public chamber of Volgograd. As the Director of the legal clinic, she carries out activities on legal education of various categories of citizens and providing free legal assistance Contact e-mail: smironova2017@gmail.com.
} 
Key words: Budget, Local Self-Government, Municipalities, Information Systems, Information Technologies, Financial Activities; The Budget Process; Participatory Budgeting; Public Control; E-Participatory Budgeting, Principle Of Transparency (Openness); Blockchain

\section{JEL Classification: H71, H72, H77}

\section{Introduction}

One of the basic principles of financial law formulated by Professor N. I. Khimicheva is the principle of participation of Russian citizens in the financial activities of the state and local governments, as well as in the implementation of its control [Khimicheva 2012: 49]. E. Belikov believes that it should not be considered as an independent principle of financial law, but as the content of the general principle of democracy, acting in financial law and having its specific manifestation [Belikov 2016]. In Russia, the study of this principle was developed in the writings of several authors, both in legal and in economic literature [Mironova 2016, 2017, 2018; Tsurcan 2014, etc.].

In other countries also focuses on the research of citizen participation in the budget process, including the implementation of the citizens' control over the spending of budget funds. For example, in the Czech Republic, «feedback between bodies of territorial selfgovernment and the population is very intense, and simultaneously we can see it in all stages of the budgetary process. Mainly the activities of municipal and regional bodies are immediately controlled by citizens, i.e. even by taxpayers and voters, in developed countries voluntarily and for no pay by citizens working in various committees, as advisory elected bodies, or possibly of executive bodies of municipalities and regions» [Pařízková 2017: 189]. In the last two decades, it has been a growing belief that broader participation in a budget setting is essential for effective, democratic, and relevant local governance [Kuriyan 2011: 29]. In the case of Wrocław in Poland, participation of the citizens in creating the participatory budget is incorporated into the concept of Smart City 3.0. Thus, the participatory budget may be the component of the area of smart governance- as an improvement of city management and smart citizens as the element of stimulating citizen activities [Bednarska-Olejniczak 2016: 761].

The hypothesis of our study is that the participation of citizens in all stages of the budgetary activity of the state and municipalities helps to increase control over the targeted expenditure of funds, the quality of budget decisions and budget execution increases the responsibility of authorities at all levels of government. The aim of the study is to analyze the impact of information technologies being introduced into the Participatory budgeting 
processes on increasing the efficiency of their use, as well as increasing the transparency of budgetary procedures.

In the course of the study, Russian and foreign websites of participatory budgeting, explicitly created for the implementation of these projects, pages of participatory budgeting on the official websites of regional and local authorities, portals of participatory budgeting, created by non-governmental organizations, pages in social networks and other Internet resources were analyzed. The analysis reveals the features of information support of projects of participatory budgeting on the Internet, as well as the use of digital technologies, such as blockchain, for voting on projects.

\section{Participatory Budgeting as a form of citizen involvement in the budget process at the municipal level}

The proximity of local self-government to the population assumes maximum involvement of the population in solving local issues, while, as noted in the report of the Ministry of Finance of the Russian Federation on the main directions of increasing the efficiency of budget expenditures in the constituent entities of the Russian Federation in 2016, many subjects of the Russian Federation note the problem of low level of interest and involvement of citizens in the budget process.

Russian citizens fulfill their powers to participate in the affairs of the state and local selfgovernment through participation in solving financial issues at the local level, i.e. through participation in the implementation of financial activities of municipalities. The financial activity of municipalities, being in a united interconnection with the financial activities of the state and being its continuation in the structure of public and legal entities, nevertheless has some peculiarities. Financial activity of municipal entities is carried out mainly by local self-government bodies. In some cases, provided for by law, other entities may be subjected performing financial activities at the municipal level. In the first place, they include population and citizens, who were given the right to make decisions on issues of local importance in some cases.

Local self-government is as close to the population as possible, and the inhabitants of a municipal formation can influence the decision-making of local authorities, including in the financial sector.

One form of such participation is the most widespread in the world the practice of participatory budgeting, which originated in 1989 in the city of Porto Alegre (Brazil) as a form of direct democracy and involving the participation of citizens in decisions on choosing priorities for spending budget funds [Dias 2018]. Currently, Brazil remains a 
country with the largest practice of participatory budgeting because it uses various $\mathrm{PB}$ practices that cover most regions of the country [Wampler 2010]. PB is distributed around the world, both in America, and in Europe, and in Asian countries. In 2019, already 70 countries apply Participatory Budgeting. The most comprehensive study of Participatory budgeting is presented in the book [Dias 2018].

Analysis of foreign legislation and practice shows that such forms of citizen participation as participatory budgeting in all its forms are successfully applied throughout the world for citizens and the state to interact in solving financial problems.

In Poland, as well as in Russia, no clear statutory regulations related to the introduction of the participatory budget, which caused a diverse use of the funds from this tool by individual local governments to various degrees and manners. The essential provision enabling the engagement of local societies in the process of defining parts of the priorities of budgetary expenditure of the units of local governments were the provisions of article $5 \mathrm{a}$ of MLGA, indicating that "local legislative bodies have the power to consult with residents on major issues for the municipality". Despite that the number of municipalities using the extended participatory budgeting mechanism has been increasing since 2013 [Olejniczak 2018].

In the Czech Republic, the city of Brno was the first one to have participatory budgeting in which ordinary people decide on how to spend a part of the local budget via democratic methods. Dáme na vás (https://damenavas.brno.cz/) is the first project of this kind in Brno and was launched at the beginning of 2017. The city has allocated 20 million crowns for the development of the projects. Each initiative may receive up to 2 million, which is the upper budget limit for one project. Many Czech cities have already joined participatory budgeting.

Russia is also actively developing Participatory Budgeting, which officially received the name of initiative budgeting. Currently, various forms of citizens' participation in addressing issues of local importance are used in Russia: initiative budgeting, participatory budgeting, people's budget, and programs to support local initiatives. Most of them are in the stage of formation and are not fixed at the federal level. The program of support to local initiatives, which began to operate in Russia in 2007 with the support of the World Bank, is the most developed in practice and used the longest of them. Each of these forms has its own peculiarities and in some cases differs from the applied foreign analogues.

Initiative budgeting, the people's budget, programs to support local initiatives have not yet been established at the federal level as a form of participation in special regulatory and legal acts. At the same time, statutory regulation is actively developing at the regional level and municipalities, this is due to objective reasons, because regional and municipal legal acts allow taking into account the local specifics, the particular municipal formation, its socio- 
economic development, and focus on those forms of citizens' participation which are relevant for the given territory.

Support programs for local initiatives were first consolidated at the federal level by the Strategy for the Social and Economic Development of North Caucasus Federal District until 2025, where support for local initiatives was identified as one of the mechanisms for implementing the optimal scenario for the development of North Caucasus Federal District. Subsequently, support for local initiatives received further regulatory development at the federal level in 2013 with the adoption of the Federal Target Program "Sustainable Development of Rural Areas for 2014-2017 and for the Period to 2020", one of the main tasks of which was to grant support to local initiatives of citizens living in rural areas.

In Appendix No. 9 to the federal target program, the Rules for granting and distributing subsidies from the federal budget to the budgets of the constituent entities of the Russian Federation for grant support of local initiatives of citizens living in rural areas were approved.

The municipal programs "Sustainable development of rural territories" are accepted. The adoption of programs at all three governmental levels shows the priority for the region to implement this program, at the same time it is important for the adopted regional and municipal programs not to contradict the federal level and to be aimed at the realization of those goals and objectives that are set in the state program of the Russian Federation.

Since programs to support local initiatives are implemented on co-financing terms, it is important to adopt appropriate regulatory legal acts of the constituent entities of the Russian Federation that establish rules for granting and allocating subsidies to municipal budgets to support local initiatives [Mironova, Kozlova 2018].

The State Program of the Russian Federation "Public Finance Management and Regulation of Financial Markets" provides for "facilitating the creation of conditions for the implementation of the practice of initiative budgeting at the level of the constituent entities of the Russian Federation and municipalities" in order to increase the transparency of information in the management of public finances, and to ensure the involvement of citizens in the discussion of budget decisions and monitoring their effectiveness and effectiveness of their implementation. The state program does not establish any mechanisms aimed at creating conditions for the implementation of the practice of initiative budgeting, in this connection regional and municipal regulatory and legal acts that implement these provisions are of interest.

At the regional level, the main directions for the development of budgetary policy also include a development of practices for initiative budgeting in the regions. 
One of the factors that testify to the need to include citizens (population) in the number of subjects of the budgetary process is their interest in resolving financial issues at the municipal level. The financial activity of municipal entities is one of the ways to manifest management activities at the municipal level through the consistent application of financial and legal mechanisms to ensure public interests related to improving the livelihoods of the population of the municipal formation.

Citizen participation in the budget process is closely related to the implementation of the principle of transparency (openness) because Participatory Budgeting involves training citizens in the basics of budget literacy and contributes to the implementation of public control over expenditures from the local budget. The principle of transparency is actively explored in the framework of financial law. For example, A. Reut associates transparency with a tax culture, which, like budget literacy, is closely related to financial literacy as a whole, shows the level of understanding of citizens of financial policy, the state as a whole, and at the municipal level [Reut 2019: 84].

The tax legal transparency principle promotes cooperation between tax authorities and taxpayers [Demin 2018: 11], which in turn is closely linked to the participation of citizens in the budget process as a deliberate payment of taxes by citizens leads to the control of their part of the expenditure of the taxes collected.

The transparency of the financial activities of the state and municipalities is facilitated by the introduction of information technology. As noted in the literature, the development and implementation of information systems in the field of public finance occurs consistently and is caused by the objective needs of society and the state, as well as the need to increase the transparency of public finance and with varying degrees of coverage the areas of public finance [Povetkina 2018: 79]. As Mariański notes «the compatibility between the technical progress and level of informatization and Fin-Tech in the private sector and in the public sector may be the most important factor for ensuring effectiveness of the local public finances» [Mariański 2018: 101]. ICTs, particularly online and mobile technology tools, are changing the transparency and accountability field [Kuriyan 2011: 5].

The introduction of information technology in Participatory budgeting also helps to increase the transparency of the budget process, although there are other points of view, for example, Pradeau notes that "French PBs are not about raising awareness about finance constraints or making budgets more transparent» [Pradeau 2018: 380]. It should be noted that the introduction of information technology requires appropriate technical training, which is impossible without financial costs. If ICT projects were implemented in technically unprepared regions, this could lead to project failure, as happened with the Enlared Municipal program in Bolivia [Gigler 2009: 187]. 
In this regard, it is necessary to consider the impact of information technologies being introduced into the Participatory budgeting processes on increasing the efficiency of their use, as well as increasing the transparency of budgetary procedures.

\section{The use of information technology in Participatory budgeting in foreign countries}

One of the modern trends in the development of $\mathrm{PB}$ is electronic participatory budgeting; the introduction of information technologies is noted everywhere in many countries that use mechanisms of citizen participation in the budget process [Nelson 2018]. At the same time, even in Brazil, which has the wealthiest PB experience, the introduction of information technology is developing gradually, use of ICTs is still not widespread in Brazilian PB. Two major metropolises and state capitals adopted digital media in PB: Belo Horizonte and Recife [Fedozzi 2018: 11]. Research conducted in 2016 on the 283 Brazilian cities with more than a hundred thousand inhabitants showed that only 12 municipalities had a digital PB tool [Lüchmann 2018: 101]. The use of these technologies do not seem to offer quick solutions, and virtual processes keep presenting the same traditional problems, such as activities restricted to the citizens, participation restricted to the local population, or a poorly developed governance communication plan which negatively impacts the efficacy of the process.

Digital participation channels are used almost exclusively to provide further channels for input (providing proposals) and output of the final results (voting or prioritizing proposals). Use of information technology in addition to traditional forms of organization of Participatory Budgeting depends on the size of the municipality. The smaller a municipality, the less likely it is to use digital tools to organize. Larger cities, for example, tend to use a combination of both forms of participation [Francés 2018: 284].

The internet is frequently used for submitting proposals and voting on them. Participatory budgeting is actively implemented via the Internet in many countries of the world (for example, in Portugal, citizens submit their proposals on the Internet, through the website www.lisboaparticipa.pt, in South Korea - using the digital portal «Digital Budget and Accounting System» («D-Brain») and etc.). Such platforms can be either pages on social networks, for example, on Facebook, or sites specially created for this purpose [Mironova 2018]. These can be general groups, for example, the Facebook group "Participatory Budgeting in the UK", designed to spread knowledge and stimulate debate on participatory budgeting in the UK. Facebook groups can be duplicated by sites - The PB Network (https://pbnetwork.org.uk/). The PB Network is designed to share information and blogs, conduct training events, publish policy-related documents, and stimulate discussions about how PB will evolve. The PB Network strives to act following the values outlined in the 
paper "Values, Principles and Standards", namely: transparency; availability; thinking; empowerment; local property; Primary participation; representative democracy; shared responsibility.

Groups can be created for individual municipalities and individual projects. For example, Facebook has the Participatory Budgeting Victoria group, which implements projects in the city of Victoria USA. Group duplicates City of Victoria Youth Council website (https://cvyc.ca/), where PB projects are also presented, online voting on projects is held. It is noteworthy that the projects are created by the Victoria Youth Council (CVYC), which is a grassroots youth program that offers opportunities for civic engagement of youth who "live, work, hang out or go to school in Victoria." It involves young people aged 14 to 24 who are key stakeholders and who should be included in decisions that affect them and their communities as a whole.

An analysis of such sites shows that pages on social networks are used mainly for information support of projects, and the projects themselves, their description, online voting is carried out on the site.

For example, a website (http://www.dirolamia.it/) has been created for PB projects in the city of Ro (province of Milan, Lombardy region, Italy), which contains detailed information on projects in general. The peculiarity of the participation of their citizens is that the proposed projects are determined by the 17 sustainable development goals defined by the UN. The goals determine the changes necessary to build a sustainable world, involving all participants in the territory in the logic of shared responsibility.

The selection of projects is carried out in the following way. At the first stage, all citizens living and visiting Ro can submit a project for the city by filling out the "Project Presentation Sheet". The competent municipal authorities then evaluate the technical and economic feasibility of the proposals submitted. Possible projects that will receive more votes in the project presentation sheets are published on the site and submitted to citizens for voting. All those who are at least 14 years old and who live in Ro can take part in the vote. Voting is possible both at special polling stations and online.

So, in 2018, 20 projects took part in the voting, 6 of which received the largest number of votes and received funding. A total of 2095 votes were cast, of which 1041 were online, so online voting for projects is a reasonably popular way for citizens to vote. The maximum amount of 200 thousand euros was received by the LA BICIPOLITANA DI RHO project, which combines sections of existing bicycle paths into a single network, fast and efficient, graphically represented as a public transport network. The project combines communication and infrastructure development to promote sustainable mobility, especially for schools and students. In total, 400 thousand euros were allocated for projects in 2018. 
Information and voting on projects can be carried out on pages located on the official website of municipalities. For example, in the city of Vicenza in Italy, on the site of the municipality, there is a special section Partecipazione, which contains materials on $\mathrm{PB}$ (https://www.comune.vicenza.it/).

Some sites can be created, uniting several municipalities implementing PB projects. For example, in Italy in 2014, BiPart was the only active platform, hosting three new PBs (Turin's district 7, Monza and Faenza), while most of the other PB initiatives still set up informative websites and basic online forms - or email addresses - to upload proposals; some still voted only on paper ballots. Today, most of the Italian PBs continue to feature very light technological solutions: for instance, Rescaldina municipality (pop. 14,300) developed its website with Google suite, while Venaria Reale (pop. 34,000) managed evoting through the open-source software Limesurvey. Campi Bisenzio (pop. 47,000) is one of the exceptions among medium cities since it created its proprietary platform for connecting $\mathrm{PB}$ and other participatory processes. Few cities use digital platforms, which are mostly managed by few consultancy agencies [Stortone 2018: 300].

A distinctive feature of some foreign PB portals is that they are created not by state structures, but by private organizations whose purpose is to disseminate PB practices. For example, in the Czech Republic? the PB are supported by The Agora Central Europe (Agora CE) civic association which was founded in 1998 with the aim of helping to enhance communication between local governments, central government bodies, and citizens. It organizes public meetings, workshops, social and cultural events, and pursues various other activities including work witch youth, aiming to meet its objectives. Agora CE makes the project of Participatory budgeting. The project itself consists of three main activities that help to meet, discuss and understand different perspectives of the participatory budget $(\mathrm{PB})$ implementation in municipalities. A special website for providing information support has been created - https:/www.participativni-rozpocet.cz/. Through this website, Participatory budgeting projects are implemented by a number of Czech cities, including Prague.

Another Czech non-profit organization Alternativa zdola also provides informational support for ongoing Participatory budgeting projects on its website (http://alternativazdola.cz/).

In Iceland, which has been operating since 2008, the Citizens Foundation as a non-profit organization based in Reykjavik, on its website https://www.citizens.is/ in the IB section offers Budget Voting \& Civic Education. To date 608 ideas have been approved by citizens in the My Neighbourhood project from 2012-2017.

Typically, such organizations receive financing from the funds for the implementation of their projects. 
Recently, there are more and more Internet platforms related to democratization and increasing the transparency of government work that can be used to engage citizens in decision-making (for example, Novoville in Greece, Polyteia in Berlin, Citizen Lab in Brussels, Civocracy and Fluicity in Europe, CHAOS in Helsinki, Discuto in Austria, Cap Collectif in Paris, Citibeats in Barcelona. Thus, both exclusive sites and portals on participatory budgeting and broader profile sites offering a variety of participation tools can be used (consultations, participatory budgeting, survey, suggestion box, call for projects, interpellation).

The given examples show the variety of information technologies used in the $\mathrm{PB}$, which helps to attract citizens to participate in the budget process and control the spending of funds.

\section{The use of information technology in Participatory budgeting in Russia}

In Russia, the use of Participatory budgeting and other forms of involving citizens in the budget process is also carried out using electronic forms of interaction and Internet technologies.

For example, in the Omsk Region, the "People's Budget" project is running (http://budget.omsk.ifinmon.ru/narodnyj-byudzhet) - all applications go through a public comment process in the form of online voting, and then they are considered by a special commission - the implementation commission The project "People's budget" in the Omsk region, which is the coordination body formed to select applications for resolving issues of socio-economic development of the Omsk region as part of the project "People's budget" in the Omsk region [Mironova 2016].

In the Tver region, programs to support local initiatives (PSLI) are being actively implemented. All information about ongoing project competitions is presented on the official website of the PSLI of the Tver Region (http://ppmi.tverfin.ru). Citizen participation is carried out through online surveys, online forums, voting via the Internet, which allows attracting a higher number of residents to the solution of issues of municipalities. Participation in such projects will enable citizens to see the real fruits of democracy because their voices and proposals can improve the territory in which they live, solve pressing problems that they face every day [Mironova 2017].

In the Sakhalin Region, the Portal of Initiative Budgeting (https://pib.sakhminfin.ru/) contributes to the active development of initiative budgeting, which is designed to help:

- increase financial and legal (budget) literacy of the population; 
- information transparency in discussing ideas and implementing projects proposed by residents of the Sakhalin Oblast;

- the expansion of partnership practices and socially oriented cooperation between public authorities, citizens, public associations, commercial and non-profit organizations;

- the creation of alternative open areas for dialogue between public authorities and citizens.

The main purpose of the portal:

- Training in initiative budgeting;

- Registration of initiatives (projects) and their discussion;

- Information support for projects at all stages;

- Alerting users by subscription;

- Informing the portal about ongoing activities;

- Conducting sociological research and surveys;

- Informing about ongoing partnership programs (projects), providing partners with a portal resource;

- Information on the conduct of competitive selection for the provision of subsidies from the regional budget.

The undoubted advantage of the initiative budgeting site of the Sakhalin Region should be called the fact that it combines several practices:

1) Support for local initiatives (small projects related to landscaping villages and urban housing estates).

2) Youth budget (a category of project proposals, the authors of which are high school students).

3) development of territories (resource-intensive design proposals affecting the scope of capital construction).

Online voting is possible on the site, while it is more popular than traditional polling. So, the last voting on the projects collected a total of 18399, of which 15925 online, 2474 in person. This vote only confirms that online voting is more profitable for municipalities from a financial point of view because online voting significantly reduces participation costs [Wampler 2018: 68]. 
The most popular are projects on cultural facilities and recreation areas, sports facilities (the leader of the vote is the project "Development of a recreation park in the city of Korsakova (sports territory)"), as well as projects related to water supply.

The portal also contains information on ongoing activities, for example, a schedule of general meetings for the selection of socially significant projects based on local initiatives for 2020.

Since April 2019, the Ugra Initiative Budgeting Center portal (http://xmao.qusilisk.beget.tech/) has been operating in Ugra, acting as a sub-portal of the more general Open Region-Ugra portal. All submitted projects are open for general use. Each project is located on a map and has an active link that translates to its location. The project card contains brief information about its main stages, its cost, divided by shares, you can observe how the project was modified.

A teaching room is working, where regulatory acts of municipalities, contact information, and meeting schedules are posted. Surveys are conducted on the site, in the future it will be possible to send an application for participation in the competition. In the "library" section, analytical information is published on the typology of projects, sources of their financing. Here you can get answers to the most frequently asked questions.

In the future, it is planned to create closed parts in this form in the form of personal accounts for both citizens and authorities for a more detailed organization of the initiative budgeting process. It is also planned to conduct educational webinars, trainings, post podcasts.

Also, initiative budgeting portals were created in the Udmurt Republic (http://ib.mfur.ru/) and a number of other regions. Also, information about ongoing projects can be posted on the websites of regional financial authorities, the region's official portal or on the pages of budget websites created for citizens (for example, in Orenburg this is the website "Budget for citizens of the Orenburg region - http://budget.orb.ru/new/init-budg). At the same time, in most cases, information on initiative budgeting projects is posted only on the official websites of regional authorities in the form of news in a very short version.

As can be seen from the presented examples, sites for initiative budgeting are created by regional government bodies and local authorities, unlike a number of foreign portals, the creation of which is initiated by private companies.

It should be recognized that it is essential to create sites, Internet portals, individual pages devoted to initiative budgeting, both at the regional and local levels. It seems necessary to continue work in this direction. The expansion of such sites will contribute to greater involvement of citizens in initiative budgeting, on the one hand, and on the other hand, 
will contribute to the implementation of the principle of open budget. In this regard, it seems necessary to provide funds in the regional budgets for the creation of such sites. Another option could be holding competitions, attracting public organizations through subsidies and grant funds to carry out this work.

As well as abroad, in Russia, social networks are actively used as platforms for initiative budgeting projects. In addition to Facebook, the Vkontakte network is more popular, where citizens create groups for information support of contests. So, as of August 1, 2019, Vkontakte has more than 150 groups of projects supporting local initiatives. More than 30 groups of projects "People's Budget", more than 10 groups of projects of initiative budgeting. These can be groups at the regional level (for example, the Project for Supporting Local Initiatives in the Novgorod Region), groups of municipal districts (PSLI Kholmsky District - Kholm City Urban Settlement), settlement level (PSLI Belebelkovsky rural settlement). Groups are actively used to raise funds (monetary participation of citizens) and assistance for certain types of work (labor participation of citizens) necessary for the implementation of projects.

Information support through the media and social networks in some regions is a prerequisite for participating in the competition and adds a certain number of points to the project evaluation, which encourages citizens to conduct such information work.

In Russian practice, one can also find the creation of sites for voting on initiative budgeting projects, for example, in the Volgograd region. According to the Finance Committee of the Volgograd Region, 209 projects took part in the final vote. For the implementation of the program of local initiatives in 2019, 49 million rubles are provided for in the budget of the Volgograd Region. The leader in public support was the Dubovskiy district project to create a celebration hall in secondary school No. 1 - he scored 2725 votes. 2170 votes were cast for the project of repairing a cinema in the city of Kotovo.

Voting was carried out on a special portal www.budget4me34.ru from May 18 to May 31, 2019, for this the Polys voting system was used on the blockchain platform from Kaspersky Lab. The procedure demonstrated the high activity of the region's residents and their interest in developing their territories - 82.5 thousand people took part in the vote, 112.6 thousand votes were taken into account. Everyone could vote for one project from each district or city - not just the one in which he lives. According to Kaspersky Lab, the online voting on the blockchain platform in the region has become the largest in the history of using this technology.

On the one hand, the use of blockchain technologies for voting on initiative budgeting projects should be evaluated positively, because such technologies help to prevent errors in the vote count and, most importantly, to avoid errors associated with this. The literature draws attention to the need to implement blockchain technologies in various areas of legal 
life (Nagrodskaya 2019), including in the financial sphere, for example, the realm of financial control, in the public sector, state and municipal orders (Brykin 2018; Lagutin 2018; Tsindeliani 2019). At the same time, the risks of such technologies to financial security, in general, should be taken into account (Kucherov, Povetkina 2018).

At the same time, the use of blockchain technologies that allow excluding changes in the counting of votes does not exclude other errors in the voting. So, to participate in the voting on projects in the Volgograd region it was enough to go to the portal, having received the code on the phone number (individual registration was not required). In this case, the user did not report any information related to registration in the Volgograd region. Thus, in fact, any citizen who visited the site could take part in the vote, without taking into account his territorial residence. Is it possible to track which of those who voted is a resident of the Volgograd region, and who is not, the system does not answer? All this can lead to incorrect voting when to increase the number of votes, residents who do not live in the corresponding territory can take part in the vote, thereby the real interests of residents of a particular municipality may not be taken into account.

The opportunity to vote not only for your locality, but also to choose one best project in each district of the Volgograd region and the city of Volgograd, also seems debatable, because a resident of Volgograd may not be aware of the needs and interests of some remote municipal area and settlement.

The possibility of errors when voting online for projects is also indicated by foreign authors. For example, in France «Digital vote happens in $44 \%$ of cases and fraud is not controlled. Only 6 cases could ask for ID check in order to prevent multiple votes» (Pradeau 2018: 378).

\section{Conclusion}

Local self-government is as close to the population as possible, and the inhabitants of a municipal formation can influence the decision-making of local authorities, including in the financial sector. Summing up the study, we can conclude that the PB is an effective tool for involving citizens in the budget process. Analysis of foreign legislation and practice shows that such forms of citizen participation as participatory budgeting in all its forms are successfully applied throughout the world in order for citizens and the state to interact in solving financial problems. The involvement of citizens in all stages of the budgetary activity of the state and municipalities helps to increase control over the targeted expenditure of funds, the quality of budget decisions and budget execution improves the responsibility of authorities at all levels of government. 
Russia is also actively developing Participatory Budgeting, which officially received the name of initiative budgeting. Currently, various forms of citizens' participation in addressing issues of local importance are used in Russia: initiative budgeting, participatory budgeting, people's budget and programs to support local initiatives. Most of them are in the stage of formation and are not fixed at the federal level. The program of support to local initiatives, which began to operate in Russia in 2007 with the support of the World Bank, is the most developed in practice and used the longest of them. Each of these forms has its peculiarities and in some cases differs from the applied foreign analogs.

Citizen participation in the budget process is closely related to the implementation of the principle of transparency (openness) because Participatory Budgeting involves training citizens in the basics of budget literacy and contributes to the implementation of public control over expenditures from the local budget. The principle of transparency is actively explored in the framework of financial law.

The transparency of the financial activities of the state and municipalities is facilitated by the introduction of information technology, which in turn increases the transparency of budgetary procedures. At the same time, the introduction of information technology requires appropriate technical training and implementation of information technology, the creation of sites, portals, etc. of regional and municipal authorities, which is impossible without financial costs. Thus, it is necessary to provide for these purposes expenses in regional and local budgets.

Digital participation channels are used almost exclusively to provide further channels for input (providing proposals) and output of the final results (voting or prioritising proposals). Use of information technology in addition to traditional forms of organization of Participatory Budgeting depends on the size of the municipality: the larger the municipality, the more difficult it is to gather people for face-to-face meetings, the more often online forms are used.

The internet is frequently used for submitting proposals and voting on them. Participatory budgeting is actively implemented via the Internet in many countries of the world. Such platforms can be either pages on social networks, for example, on Facebook, or sites specially created for this purpose. An analysis of such sites shows that pages on social networks are used mainly for information support of projects, and the projects themselves, their description, online voting is carried out on the site. Analysis of voting for projects in different cities and countries shows that online voting is gaining more popularity. Online voting is more profitable for municipalities from a financial point of view because online voting greatly reduces participation costs. 
A distinctive feature of some foreign PB portals is that they are created not by state structures, but by private organizations whose purpose is to disseminate PB practices. Typically, such organizations receive financing from the funds for the implementation of their projects.

In Russia, the use of Participatory budgeting and other forms of involving citizens in the budget process is also carried out using electronic forms of interaction and Internet technologies. Online voting is possible on the site, while it is more popular than traditional voting.

Most sites for initiative budgeting are created by regional government bodies and local authorities, unlike a number of foreign portals, the creation of which is initiated by private companies. The expansion of such sites will contribute to greater involvement of citizens in initiative budgeting, on the one hand, and on the other hand, will contribute to the implementation of the principle of open budget. In this regard, it seems necessary to provide funds in the regional budgets for the creation of such sites. Another option could be holding competitions, attracting public organizations through subsidies and grant funds to carry out this work.

As well as abroad, in Russia, social networks are actively used as platforms for initiative budgeting projects. In addition to Facebook, the Vkontakte network is more popular, where citizens create groups for information support of contests. Groups are actively used to raise funds (monetary participation of citizens) and assistance for certain types of work (labor participation of citizens) necessary for the implementation of projects. Information support through the media and social networks in some regions is a prerequisite for participating in the competition and adds a certain number of points to the project evaluation, which encourages citizens to conduct such information work.

A promising direction should be called the use of blockchain technologies for voting on projects, as it was used in the Volgograd region in Russia. On the one hand, the use of blockchain technologies for voting on initiative budgeting projects should be evaluated positively, because such technologies help to avoid errors in the vote count and, most importantly, to prevent the mistakes associated with this.

At the same time, the use of blockchain technologies that allow excluding changes in the counting of votes does not exclude other errors in the voting. It is necessary to provide a mechanism to prevent the voting of citizens who do not live in the area, re-voting and other violations. This problem is typical not only for Russia, but also for other countries that use online voting, and requires its further solution. 


\section{References:}

Bednarska-Olejniczak, D., Olejniczak, J.: Participatory budget of Wrocław as an element of Smart City 3.0 concept, in: Klímová, V., Žítek, V.: Conference: XIX. mezinárodní kolokvium o regionálních vědách (conference proceedings), Cejkovice, Brno: Masaryk University Press, 2016.

Belikov, E.: Razvitie principa demokratizma $\mathrm{v}$ finansovom prave $\mathrm{v}$ usloviyah formirovaniya social'nogo gosudarstva [The development of the principle of democracy in financial law in the context of the formation of a social state], Gosudarstvennaya vlast' i mestnoe samoupravlenie [State power and local self-government] No. 4, 2016.

Brykin, K.: Blokchejn kak sredstvo realizacii principa prozrachnosti (otkrytosti) v sfere publichnyh finansov [Blockchain as a Mean of Transparency Principle Implementation in the Public Finance Sector], Finansovoe parvo [Financial law], No. 4, 2018.

Demin, A.: New model of tax administration. Change of paradigm, Financial Law Review, No. 10 (2), 2018.

Fedozzi, L., Furtado, A. \& Rangel, R.: Participatory Budgeting in Brazil: Elements for a Brief Evaluation in: Hope for Democracy: 30 years of Participatory Budgeting Worldwide, Nelson Dias, 2018, Available at: Available at: https://www.oficina.org.pt/hopefordemocracy.html\#.

Khimicheva, N. (ed.): Finansovoe pravo [Financial law], Moscow: Norma Publ., 2012.

Tsindeliani, I.A. (ed.): Finansovoe pravo $\mathrm{v}$ usloviyah razvitiya cifrovoj ekonomiki [Financial Law in a Digital Economy], Moscow, 2019.

Francés, F., Carratalá, L. \& Ganuza, E.: 20 Years of Participatory Budgeting in Spain in: Hope for Democracy: 30 years of Participatory Budgeting Worldwide, Nelson Dias, 2018, Available at: https://www.oficina.org.pt/hopefordemocracy.html\#.

Gigler, B.-S.: Decentralization, Clientelism and Popular Participation-Is there a role for ICTs to improve local governance? in: 3rd International Conference on Information and Communication Technologies and Development (conference proceedings), Piscataway: IEEE Press, 2009.

Kuriyan, R., Bailur, S., Gigler, B.-S., Park, K.: Technologies for Transparency and Accountability: Implications for ICT policy and Implementation, World Bank 2011.

Lagutin, I., Suslikov, V.: Pravovoe obespechenie blokchejn-tekhnologij (voprosy teorii i praktiki) [Legal Support of Blockchain Technologies (Issues of Theory and Practice)], Finansovoe pravo (Financial law), No. 1, 2018.

Lüchmann, L., Romão, W. \& Borba, J.: 30 years of Participatory Budgeting in Brazil: the lessons learned in: Hope for Democracy: 30 years of Participatory Budgeting Worldwide, Nelson Dias, 2018, Available at:

https://www.oficina.org.pt/hopefordemocracy.html\#.

Mariański, M.: Challenges and Problems of Local Government Finances in the Light of the French Cour des Comptes Reports as a Guide for the Polish Legislature, in: Mrkývka P., Gliniecka J., Tomášková E., Juchniewicz E., Sowiński T., Radvan M. (eds.), The challenges of local government financing in the light of European Union regional policy. Conference Proceedings. Brno: Publications of the Masaryk University, Theoretical Series, Edition Scientia, 2018. 
Mironova, S., Kozlova, M.: Participation of citizens in the financial activities of municipalities: the experience of Russia and other countries, in: Mrkývka P., Gliniecka J., Tomášková E., Juchniewicz E., Sowiński T., Radvan M. (eds.), The challenges of local government financing in the light of European Union regional policy. Conference Proceedings. Brno: Publications of the Masaryk University, Theoretical Series, Edition Scientia, 2018.

Mironova, S.: «Narodnyj byudzhet» kak forma uchastiya grazhdan $\mathrm{v}$ finansovoj deyatel'nosti gosudarstva i municipal'nyh obrazovanij ["People's budget" as a form of citizen participation in the financial activities of the state and municipalities], Vestnik Volgogradskoj akademii MVD Rossii [Bulletin of the Volgograd Academy of the Ministry of Internal Affairs of Russia], No. 4, 2016.

Mironova, S.: Finansovo-pravovye aspekty privlecheniya naseleniya $\mathrm{k}$ effektivnomu ispol'zovaniyu byudzhetnyh sredstv na municipal'nom urovne [Financial and legal aspects of attracting the population to the efficient use of budget funds at the municipal level], Biznes. Obrazovanie. Pravo. Vestnik Volgogradskogo instituta biznesa [Business. Education. Right. Bulletin of the Volgograd Institute of Business] No. 1 (38), 2017.

Mironova, S.: Uchastie grazhdan v finansovoj deyatel'nosti municipal'nyh obrazovanij kak princip finansovogo prava [Participation of citizens in the financial activities of municipalities as a principle of financial law], Moscow, 2018.

Nagrodskaya, V.: Novye tekhnologii (blokchejn / iskusstvennyj intellekt) na sluzhbe prava [New technologies (blockchain / artificial intelligence) in the service of law], Novoselova, L.A. (ed.): Moscow, 2019.

Bednarska-Olejniczak, D., Olejniczak, J.: Participatory Budgeting in Poland in 2013-2018 Six Years of Experiences and Directions of Changes in: Hope for Democracy: 30 years of Participatory Budgeting Worldwide, Nelson Dias, 2018, Available at: https://www.oficina.org.pt/hopefordemocracy.html\#.

Pařízková, I.: The Budgetary Process of Territorial Self-Governing Units in the Czech Republic (in:) Mrkývka P., Gliniecka J., Sowiński T., Radvan M. (eds.), The financial law towards challenges of XXI century. Conference proceedings, Brno: Masaryk University Press, 2017.

Povetkina, N.: The concept of development of human rights in the sphere of public finance in the Russian Federation, Financial Law Review, No. 10 (2), 2018.

Pradeau, G.: A third wave of Participatory Budgeting in France in: Hope for Democracy: 30 years of Participatory Budgeting Worldwide, Nelson Dias, 2018, Available at: https://www.oficina.org.pt/hopefordemocracy.html\#.

Reut, A.: Legal measures of overcoming tax culture shocks and tax culture lags, Financial Law Review, No. 2, 2019.

Riski finansovoj bezopasnosti: pravovoj format [Financial Security Risks: Legal Format], Kucherov I.I., Povetkina N.A. (eds.), Moscow, 2018.

Stortone, S. \& Allegretti, G.: Participatory Budgeting in Italy. Towards a Renaissance? in: Hope for Democracy: 30 years of Participatory Budgeting Worldwide, Nelson Dias, 2018, Available at: https://www.oficina.org.pt/hopefordemocracy.html\#.

Tsurcan, M.: Modernizaciya i razvitie obshchestvenno-infrastrukturnogo kompleksa regiona v kontekste Programmy podderzhki mestnyh iniciativ [Modernization and 
development of the public-infrastructure complex of the region in the context of the Program for Support of Local Initiatives], Tver, 2014.

Wampler, B., McNulty, S. \& Touchton, M.: The Global Spread and Transformation of Participatory Budgeting in: Hope for Democracy: 30 years of Participatory Budgeting Worldwide, Nelson Dias, 2018, Available at:

https://www.oficina.org.pt/hopefordemocracy.html\#.

Wampler, B.: Participatory Budgeting in Brazil: Contestation, Cooperation, and Accountability. Pennsylvania State University Press, 2010. 